\title{
PENDAMPINGAN PEDAGANG DALAM PRAKTEK GARANSI (KHIYAR) PADA TRANSAKSI BAI' AL - MUSAWAMAH DI PASAR TRADISIONAL WADUNG ASRI WARU SIDOARJO
}

\author{
Oleh: \\ Abdul Majid Toyyibi \\ Sekolah Tinggi Agama Islam Al Fithrah Surabaya \\ E-mail: abdulmajidtoyyibi93@gmail.com
}

\begin{abstract}
Abstrak:
Khiyar adalah meminta yang terbaik dari dua pilihan yakni melanjutkan atau membatalkan transaksi jual - beli. Tujuan dilakukan pengabdian yakni untuk para pedagang Pasar Wadungasri bahwa dalam bertransaksi jual beli untuk menerapkan akad khiyar. Hal ini merupakan bagian kecil dari strategi penjualan untuk menjadikan pembeli merasakan nyaman dan puas membeli barangnya. Sehingga barang barang yang di transaksikan mempunyai nilai barokah pada income yang diperoleh penjual. Adapun metode yang dilakukan adalah ada beberapa tahap mulai pelatihan hingga pendampingan dalam praktek khiyar/garansi tersebut.
\end{abstract}

Kata Kunci: Khiyar, Bai Musawamah, dan Pasar

\section{PENDAHULUAN}

Islam menempatkan pasar bahwa kedudukan yang terpenting dalam pengembangan perekonomian. Praktik muamalah dalam masa Rasulullah SAW dan Khulafa Al-Rasyidin menunjukkan adanya peranan pasar yang besar. Ketika seorang sahabat sampai di Madinah setelah melakukan hijrah dari Makkah maka yang pertama dilakukan adalah membangun bisnis dipasar, karena sahabat mengetahui bahwa pasarlah tempat bertemunya produsen, konsumen dan distributor. Pasar merupakan tempat pertemuan antar manusia untuk memenuhi kebutuhan hidup nya.

Taraf hidup dan pendapatan seseorang memiliki hubungan timbal balik. Rendahnya taraf hidup seseorang disebabkan oleh rendahnya tingkat pendapatan. 
Rendahnya pendapatan seseorang disebabkan rendahnya tingkat produktifitas tenaga kerja. Rendahnya tingkat produktifitas tenaga kerja disebabkan oleh tingginya pertumbuhan tenaga kerja, angka pengangguran dan rendahnya rendahnya investasi perkapita. ${ }^{1}$

Keberadaan pasar menurut masyarakat tradisional sangat penting karena pasar merupakan tempat atau lokasi untuk memenuhi kebutuhan sehari-hari. Dan di pasar juga, masyarakat bisa melakukan kegiatan jual beli atau transaksi baik dalam bentuk barang maupun jasa. Sehingga masyarakat yang memandang mata pencaharian utamanya, menjadi sangat penting adanya pasar tradisional yang masih bertahan.

Pasar tradisional harus tetap dijaga keberadaanya sebab ia adalah representasi dari ekonomi rakyat, ekonomi kelas bawah, serta tempat bergantung para pedagang skala kecil-menengah. Pasar tradisional merupakan tumpuan bagi para petani, peternak, atau produsen lainnya selaku pemasok. ${ }^{2}$ Pasar juga dikatakan salah satu tempat utama dalam perputaran roda perekonomian suatu negara. Karena disana ada transaksi ekonomi yang berputar secara terus menerus sehinggasaat ini banyak jenis pasar yang ada di berbagai tempat terutama di Indonesia sendiri. Hal tersebut bagian dari manifestasi kreatif dalam perkembangan pasar yang merubah dalam proses transaksinya. Beberapa contoh jenis pasar antara lain adalah pasar tradisional, dan pasar modern. Pasar tradisional adalah tempat bertemunya penjual dan pembeli dengan ditandai dengan adanya transaksi secara langsung dan pembeli bisa melakukan proses tawar-menawar.

Adapun pasar modern contohnya seperti supermarket dan minimarket. Pasar modern tidak melakukan transaksi secara langsung. Karena pembeli akan melihat langsung label harga yang sudah ditentukan atau ditempel sebelumnya dan tidak bisa ditawar, kemudian pembeli akan membayarnya di kasir dengan atau dilayani oleh pramuniaga. Namun jenis pasar di atas tidak lepas dari fungsi sebuah

\footnotetext{
${ }^{1}$ Universitas Sumatra Utara, "Kemiskinan", dalam http://repossitory.usu.ac.id

2 Herman Malano, Selamatkan Pasar Tradisional: Potret Ekonomi Rakyat Kecil, (Jakarta: PT Gramedia Pustaka Utama,2011), hlm.159
} 
pasar secara umum yaitu, tempat berlangsungnya jual beli sebuah produk berupa barang atau jasa. Pasar juga pada dasarnya merupakan sebuah tempat di mana terdapat interaksi antara dua belah pihak atau lebih yang sama-sama memiliki tujuan. Pembeli dengan tujuan untuk mendapatkan yang dia inginkan atau butuhkan, penjual dengan tujuan untuk mendapatkan penghasilan dengan menjual produknya.

Pertemuan antara penjual dan pembeli merupakan kesepakatan yang dihasilkan oleh keduanya berupa harga yang menjadi tawar menawar pada transaksi tersebut. Sehingga dari kesepakatan diatas dengan melalui transaksi jual beli disebut jual beli musawamah. Bai' al musawamah adalah jual-beli biasa, dimana penjual tidak memberitahukan haga pokok dan keuntungan yang didapatnya. ${ }^{3}$ Dalam transaksi ini pembeli memiliki kebebasan dalam penawaran harga barang yang bakal di beli, transaksi seperti ini yang biasa dilakukan oleh masyarakat di pasar. Namun seiring dengan terjadinya transaksi itu, penjual juga harus tunduk dan menerapkan prinsip bermuamalah karena akan berkelanjutan pada nilai barokah yang di dapat berupa laba dan terlebih pada kemajuan usahanya, mereka (penjual) mengedepankan kenyamanan, kemaslahatan, dan kepuasan dalam bertransaksi.

Untuk mewujudkan transaksi yang jujur dan adil dalam masyarakat Rasulullah SAW melarang semua bentuk pertukaran yang curang karena sebuah akad jual beli itu sah atau tidaknya tergantung pada pemenuhan syarat dan rukunya. ${ }^{4}$ Untuk mendapatkan kenyamanan, kemaslahatan dan kepuasan pada pembeli, penjual perlu memperhatikan aspek garansi atau khiyar. Adapun khiyar yang dimaksud tinjau dari segi bahasa berarti memilih yang terbaik, sedangkan pengertian khiyar menurut istilah syara' merupakan penjual dan pembeli boleh memilih antara meneruskan atau mengurungkan jual belinya. Tujuan dari khiyar sendiri bahwa agar kedua belah pihak yang bertransaksi

3 Zainul Arifin. Dasar-dasar Manajemen Bank Syariah, (Jakarta: Pustaka Alfabet, 2012), hlm. 26-27

${ }^{4}$ Sayyid Sabiq, Fiqih Sunnah, (Bandung: Al Ma'arif,1993), hlm 57. 
memikirkan kemaslahatan, agar tidak terjadi penyesalan dikemudian hari dari dampak transaksi jual beli tersebut.

Dari definisi yang telah dikemukakan di atas dapat diambil intisari bahwa khiyar adalah pilihan untuk melanjutkan jual beli atau membatalkannya, karena terdapat cacat terhadap barang yang dijual, atau ada perjanjian pada waktu akad, atau karena sebab yang lain. Tujuan diadakannya khiyar tersebut adalah untuk mewujudkan kemaslahatan bagi kedua belah pihak sehingga tidak ada rasa menyesal setelah akad selesai, karena mereka sama-sama rela atau setuju. ${ }^{5}$

Dalam islam strategi tersebut bisa menggunakan garansi atau bahasa ekonomi islamnya adalah khiyar. Khiyar ini jarang sekali diketahui oleh pelaku pasar. Padahal sebelum adam smith mempamerkan sistem garansi yang ada di sistem ekonominya, islam sudah diajarkan khiyar atau garansi. Sehingga nampak sekali apabila pengunjung Pasar Wadungasri sepi dari pembeli meskipun khiyar disini bukan menjadi penyebab utama. Namun peneliti beranggapan adanya strategi seperti ini setidaknya memberikan perubahan pada nilai income pelaku pasar. Sehingga perlu diadakannya pendampingan di Pasar Wadungasri.

Pasar Wadungasri merupakan kategori pasar tradisional yang mana dalam pengelolaannya menjadi tanggung jawab Pemerintah Kabupaten Sidoarjo. Keberadaan Pasar Wadungasri mulanya hasil reorganisasi dari dinas pasar, hal itu berubah karena manajemen pengelolaannya dalam mengembangkan pasar tidak sesuai dengan perkembangan tehnologi dan persaingan global yang menuntut berbagai pelayanan cepat serta transparansi. Sehingga seiring dengan nawa cita kabupaten sidoarjo sebagai kota metropolitan menuntut kualitas pelayanan di berbagai bidang termasuk pemasaran dan persaingan usaha yang kompetitif.

\section{METODE PENGABDIAN}

Pendekatan dalam pemberdayaan kali ini mengunakan pendekatan Action Research yang berarti kata action dalam konteks ini adalah tidak hanya ikut

\footnotetext{
${ }^{5}$ Syafii Antonio, Bank Syariah, (Bogor: Tazkia Press, 2008), hlm. 216
} 
berpartisipasi, melainkan melakukan upaya-upaya yang kiranya dapat memberdayakan pelaku pasar (penjual/pedagang) agar dapat menguasai khiyar setelah selesai melakukan pelatihan secara langsung atau kondisional keadaan pasar saat pengabdian. Berikut tahapan dalam melakukan pengabdian.

Sosialisasi Pengabdian Sebagai langkah awal di lokasi pengabdian melakukan identifikasi lebih lengkap mengenai tatacara pelayanan pedagang kepada konsumen serta melakukan sosialisasi pelaksanaan program pengabdian masyarakat yang akan dilakukan di lokasi mitra. Pada tahap ini juga akan diidentifikasi siapa saja yang akan menjadi koordinator dalam pelaksanaan program ini.

Pelatihan tentang Garansi (Khiyar), Sesuai dengan tanggal pelatihan yakni 13 Juni 2020 tepatnya jam 11.00 WIB dilakukan pelatihan secara kolektif dengan melakukan kunjungan secara bergantian, karena situasi yang tidak memungkinkan melakukan perkumpulan maka dilakukan secara bergantian sesuai dengan jam lengang para pedagang yang masuk daftar list

Monitoring dan Evaluasi Praktek Garansi Khiyar, Monitoring dan evaluasi dilakukan dengan melakukan evaluasi mengenai kendala kendala yang dihadapi serta upaya untuk menyelesaikannya Evaluasi dilakukan secara bertahap.

1. Evaluasi tahap pertama yaitu evaluasi yang dilakukan untuk mengetahui peningkatan pengetahuan masyarakat mengenai praktek Garansi.

2. Evaluasi tahap kedua yaitu evaluasi yang dilakukan untuk mengetahui peningkatan kemampuan masyarakat dalam mengimplementasikan hasil pelatihan yang telah mereka terima serta mengetahui partisipasi masyarakat dalam kegiatan PKM yang diusulkan.

3. Evaluasi tahap ketiga yaitu evaluasi yang dilakukan untuk mengetahui tingkat keberhasilan pelaksanaan PKM secara keseluruhan. Evaluasi ini dilakukan pada periode terakhir masa PKM bersamaan dengan pembuatan laporan akhir pelaksanaan PKM. 


\section{HASIL DAN PEMBAHASAN}

Kegiatan Pengabdian KeMasyarakat yang dilaksanakan dengan acara tatap muka dan praktek Garansi (Khiyar) berjalan dengan baik dan lancar. Pertemuan tatap muka dengan metode ceramah dan demonstrasi, dilanjutkan latihan/praktek untuk membuat buku saku, mulai dari pemilihan materi, dan penyusunan. Kegiatan ini dilaksanakan yaitu mulai pada tanggal 2 Juni 2020 dari pukul 11.00 WIB.

Peserta kegiatan berjumlah 5 orang pedagang. Pelaksanan kegiatan PKM ini dilakukan oleh 1 (satu) orang pengabdi dengan pokok bahasan yang disampaikan mengenai:

1. Pengantar garansi (khiyar)

2. Dasar hukum garansi (khiyar)

3. Jenis-jenis garansi (khiyar)

4. Langkah-langkah tehnis penggunaan garansi (khiyar)

5. Latihan praktek garansi (khiyar)

6. Evaluasi hasil pelatihan.

Keterbatasan waktu pertemuan dan tingkat pemahaman yang rendah maka bisa dikatakan tidak maksimal. Kegiatan yang diawali dengan ceramah dan demonstrasi ini kemudian dilanjutkan latihan. Dari kegiatan latihan tampak pedagang bingung dan belum menguasai cara praktek yang baik, khususnya ketika dibingungkan dengan memilih jenis yang akan dipakai.

Acara kemudian dilanjutkan sesi tanya jawab. Berbagai pertanyaan diajukan secara antusias oleh para pedagang dalam sesi tanya jawab. Secara garis besar inti dari pertanyaan para peserta adalah:

1. Apa yang harus dipersiapkan sebelum mempraktekkan garansi

2. Langkah-langkah penyampaian garansi

3. Penggantian jenis garansi yang dipraktekkan

4. Dampak positif kalau mempraktekkan garansi

Hasil pelatihan ini akan bermanfaat bagi pedagang, proses berdagang akan lebih menarik dengan adanya hal baru yakni garansi barang atau produknya yang 
lebih bervariasi, serta bisa memberikan kemajuan atau peningkatan profit usaha nya. Adapun Sasaran Kegiatan pengabdian ke masyarakat mengenai praktek garansi (khiyar) ditujukan pada pedagang pasar wadungasri waru sidoarjo. Sebanyak 5 pedagang terlibat dalam kegiatan ini dan mereka tersebar dalam berbagai produk jualan yang berbeda mulai dari kaos, maenan, dan lain sebagainya.

Sehingga Hasil Kegiatan Pendampingan tentang praktek garansi (khiyar) di ikuti 5 pedagang pasar wadungasri waru sidoarjo. Pada saat pelaksanaan kegiatan terlihat antusiasme pedagang dengan berbagai pertanyaan yang dilontarkan oleh pedagang. Pemahaman dan penerapan secara langsung yang disesuaikan dengan kondisi lapangan merupakan hasil dari pelatihan yang diberikan.

\section{KESIMPULAN}

Kegiatan pengabdian kepada masyarakat mengenai pendampingan pedagang dalam praktek garansi (khiyar) telah terlaksana dengan baik dan mendapatkan respon yang antusias baik sekali dari pedagang pasar wadungasri Waru Sidoarjo. Kegiatan pengabdian seperti ini dapat dilakukan secara rutin baik di lokasi yang sama maupun di lokasi yang berbeda dengan sasaran pedagang yang benar-benar membutuhkan tata cara atau management yang baik terutama mengenai garansi (khiyar).

\section{UCAPAN TERIMA KASIH}

Dalam penyeleseain pengabdian masyarakat ini tentunya penulis mendapati banyak motivasi, dorongan dan semangat dari keluarga, kolega di STAI Al Fithrah Surabaya tentunya penulis sangat mengucapkan terimakasih yang tidak ada batasnya. 


\section{DAFTAR PUSTAKA}

Universitas Sumatra Utara, "Kemiskinan", dalam http://repossitory.usu.ac.id

Malano, Herman. Selamatkan Pasar Tradisional: Potret Ekonomi Rakyat Kecil, Jakarta: PT Gramedia Pustaka Utama,2011.

Arifin, Zainul. Dasar-dasar Manajemen Bank Syariah, Jakarta: Pustaka Alfabet, 2012.

Sabiq,Sayyid. Fiqih Sunnah. Bandung: Al Ma'arif,1993.

Antonio,Syafii. Bank Syariah. Bogor: Tazkia Press, 2008. 